\title{
Insolvency and Bankruptcy Code, 2016: A Paradigm Shift within Insolvency Laws in India
}

\author{
ANKEETA GUPTA
}

\begin{abstract}
This article examines the contemporary debate surrounding the system of credit delivery and availability in India in light of the changes brought about by the Insolvency and Bankruptcy Code, 2016. The introduction of the Code is purported to resolve the issues within the credit ecosystem by identifying correctly all the stakeholders, most importantly the creditors and the debtors, resolving and settling non-performing assets, creating a robust mechanism for settling credit-related disputes, reducing creditor distrust and ensuring continuance of functioning of companies rather than being wound up for non-payment of debts. While the Code promises to be a game changer, there exist various challenges that need to be addressed as the success of the Code is dependent on the manner in which its provisions are implemented, especially those pertaining to the strict timelines with parties seeking excessive discretionary indulgence from the adjudicatory authorities. Further, the challenges include impact of differential treatment meted out to the creditors, the committee of creditors being ordained with considerable powers over the fate of the corporate debtor, and the insolvency professionals being allowed to run the entities without much accountability and capability has resulted in an increased number of disputes. The legal, logical and procedural hurdles thus mentioned will need to be addressed in the most amicable manner within the foreseeable future.

Keywords: insolvency, bankruptcy, sick companies, insolvency professionals, information utilities, committee of creditors, financial creditors, operational creditors
\end{abstract}

\section{Introduction}

India has often been chided for having fallen behind in terms of the development of its corporate economy by failing to keep up with global trends. In line with the vision of India's prime minister Narendra Modi, various initiatives have been undertaken so as to improve the international image of India's corporate economy by introducing ground-breaking legislation that will go a long way in paving the path for economic growth and development in the country (Thakar and Thakar 2016). 
Since 2014 India has witnessed a marked improvement within the corporate sector in terms of legal, procedural and ritualistic practices. Over time these had become archaic, thereby hindering business development and growth. With the election of the new government in 2014 significant positive changes have been carried out so as to improve the entire financial and corporate ecosystem, including introduction of a goods and service tax, the Amended Arbitration and Conciliation Act, labour reform and, most importantly, the introduction of the Insolvency and Bankruptcy Code, 2016. This is by far the most important single piece of legislation that was lacking from India's statute books, considering the very large number of non-performing assets (NPAs) that the Indian banking system is currently saddled with (Jain 2017).

The Insolvency and Bankruptcy Code (hereinafter referred to as 'the Code') provides a consolidated mechanism for resolving corporate insolvency in India. It seeks to induce efficiency within the insolvency and bankruptcy law regime by separating the commercial and judicial aspects of the insolvency and bankruptcy process. The Code stands on four pillars: Insolvency and Bankruptcy Board of India (IBBI, the regulator), the National Company Law Tribunal and the National Company Law Appellate Tribunal (the unified adjudicatory authority), insolvency professionals and information utilities. The Code has revamped the earlier mechanism of debt resolution to be more efficient and effective. It has greatly strengthened the legal infrastructure pertaining to the liquidation, rehabilitation and revival of failing commercial entities, which promises to improve India's ranking on the Ease of Doing Business Index. In a significant move, the Code marks a departure from the earlier approach of 'debtor in possession' to 'creditor in possession'. The Code will play a vital role in strengthening the country's credit ecosystem.

This article critically analyses the provisions of the Code in detail, delving into the history of insolvency and bankruptcy rules prior to the coming of the Code in the first section. The second section details the basic features of the Code. The third section covers the challenges that the Code has brought to the fore, while the fourth discusses the success of the Code. The article ends with a conclusion and a summary of arguments.

\section{History of Insolvency Laws in India}

India has had the dubious distinction of having chequered laws for solving insolvency and bankruptcy cases. For many years the Provincial Insolvency Act of 1920 and Presidency Insolvency Act of 1909 
addressed bankruptcy and insolvency issues. Subsequently these laws were replaced by an array of statutes. Provisions relating to insolvency and bankruptcy for companies and financial firms were found in the Sick Industrial Companies (Special Provisions) Act, 1985 (SICA), the Recovery of Debt Due to Banks and Financial Institutions Act, 1993 (RDDBFI), the Securitization and Reconstruction of Financial Assets and Enforcement of Security Interest Act, 2002 and the Companies Act, $2013 .{ }^{1}$ Individual bankruptcy and insolvency was dealt with by the Presidency Towns Insolvency Act, 1909 and the Provincial Insolvency Act, 1920, and was therefore the responsibility of the Courts. The Reserve Bank of India has from time to time introduced various schemes, rules and regulations in order to reduce the instances of loan default, and consequently the instances of NPAs, with the intention of realizing as much of the loan amount as possible. These measures included the Corporate Debt Restructuring Scheme, a Joint Lenders Forum with strategic debt restructuring, and the sustainable structuring of stressed assets (Pahwa 2010). SICA was the single most important statute pertaining to the insolvency and bankruptcy of companies; the others were merely its offshoots/extensions. Thus, SICA and the RDDBFI are discussed in some detail below.

\section{The Sick Industrial Companies (Special Provisions) Act, 1985}

SICA was the result of a high-powered expert committee constituted by the Reserve Bank of India under the chairmanship of Mr T. Tiwari. It suggested that a robust mechanism was required to revive and rehabilitate sick industrial companies. Its jurisdiction included industrial companies that were listed in Schedule I to the Industries (Development and Regulation) Act, 1951 and government companies (Narayanan 1994a: 362). The onus of reporting sickness to the Board for Industrial and Financial Reconstruction (the Board, BIFR) lay with the board of directors of the potentially sick company, the Reserve Bank of India, central government and/or financial institutions that had an interest in the company. The law provided that reference was required to be made within a period of two months from the date of discovery of sickness, and the Board was mandated to deliver a verdict and ensure that a scheme of rehabilitation was implemented within 90 days of the date of the order (Pahwa 2010). The law also placed a moratorium on all transactions, whether financial, commercial or legal, until the scheme was approved by the Board. The statute was well drafted, but a lot of discretionary powers were extended to the Board. This eventually led 
to unrealistic and unreasonable time extensions, which in effect marred the chance of a company recovering. The law only catered for a specific set of companies, which reduced the applicability and in effect the efficacy of the statute.

\section{Recovery of Debt Due to Banks and Financial Institutions Act, 1993}

This was introduced because the banking sector felt that a specialized law was required pertaining to and addressing the dire need for the realization of debts due to banks and financial institutions. It is pertinent to note that the banking system forms the backbone of the corporate economy and cannot be expected to function without adequate checks, balances and the consequent realization of debts (Dubey 2013). The basic purpose and object of this Act was the expeditious recovery of debts due to banks. It substituted for the process of the courts in relation to recovery suits for bank dues, as provided for within the Code of Civil Procedure, 1905. Proceedings under the Act were calculated to counter the dilatory tactics adopted by the recalcitrant litigants (Chandrasekhar 2018). The Act was a complete code in itself, as far as the recovery of debt by financial institutions was concerned.

While analysing the reasons for requirement of the new law, it was observed that even though the object behind SICA and RDDBFI was the revival of sick companies and the settling of debts due to banks and financial institutions, not too many revivals took place, and in the process a protective wall was created such that creditors failed to realize their debts from the debtors (Srivastava and Yadav 1986). This led the NPAs to become even more unserviceable, which eventually drove down the banks' balance sheets. It was thus considered that laws permitting the squandering of wealth rather than consolidation and revival should best be removed from the statute books, rather than being allowed to become a burden on the entire economy.

\section{Insolvency and Bankruptcy Code, 2016}

As has been indicated, the Code is aimed at bringing about a paradigm shift within India's insolvency and bankruptcy laws. Therefore, a discussion of the constitutionality, objectives and features of the statute is required, in order to assess the success of the law. 


\section{Constitutional Law Provisions}

The Indian Constitution, which is the suprema lex for the country, enumerates the manner in which insolvency and bankruptcy proceedings shall be undertaken. The insolvency and bankruptcy aspect of corporate law has been listed in the Concurrent List, entry 9, given under Schedule VII, article 246 of the Constitution, which gives both central government and the states the power to make laws and rules on the subject (Jain 2014). Since India is a federation, there exists a division of powers between central and state governments. The Concurrent List includes all those subjects on which both central government and the states can make laws. However, if any state law is found to be in opposition to a law made by central government, the Supreme Court can strike the relevant provision from the statute book.

The constitutional validity of the Code was discussed at length by the Supreme Court of India in the celebrated case of Innoventive Industries Limited, ${ }^{2}$ where it was observed that the Code, being the central law, prevailed over all existing laws pertaining to insolvency and bankruptcy.

\section{Objectives of the Code}

The objectives of the Code are manifold, but its primary purpose was to plug the loopholes that existed in earlier legislation, as discussed in the previous section. Further, it enabled the creation of a new institutional framework consisting of an Insolvency and Bankruptcy Board, professional insolvency agencies, information utilities and adjudicating authorities, thus offering uniform and comprehensive legislation for the facilitation of time-bound insolvency resolution and liquidation. Finally the Code aimed to improve the ease of doing business in India and to set up better and faster debt recovery mechanisms (Wadhwa 2016: 23-29). Thus, the Preamble of the Code clearly lays down its primary objectives:

1. 'to merge and modify the laws relating to reorganization and insolvency resolution of corporate persons, partnership firms and individuals in a time bound manner'.

2. 'maximization of value of assets of such persons, to promote entrepreneurship, availability of credit and balance the interests of all the stakeholders'.

3. to set up an insolvency and bankruptcy board of India.

Narayanan (1994b: 250) observes that the major problems for the existing mechanism for solving insolvency and bankruptcy issues were a multiplicity of laws, overlapping jurisdictions and limited links between 
the existing statutes. These obstacles ultimately resulted in delays to the resolution process for insolvencies, leading to frustration among all stakeholders, especially creditors who were deprived of their right to credit realization. With all the relevant laws coming together under one roof, with a single authority for adjudication and regulation, there is hope that bankruptcy proceedings will be resolved in a timely manner. It is for this reason that the Code has been made applicable to companies, limited liability partnerships, firms and individuals.

It is important to have a robust mechanism for resolving insolvency issues and opting for an appropriate mechanism that promises revival and rehabilitation/liquidation of companies in the shortest possible time. A delay often results in loss to the economy in terms of resources, production, employment and development of the industry concerned, leading to poor growth and development (Ayotte and Skeel 2010). It also leads to a trust deficit among the creditors, who in order to ring fence themselves lend selectively and become wary of investing in entrepreneurial initiatives or small-scale industries. In the past creditors received few rights and little legal protection when it came to the recovery of dues in the event of a default, as the erring promoters and management would more often than not remain in full control of company assets (Jongho Kim 2009: 119).

That creditors have often been handed a raw deal is indicated by the fact that they were willing to take huge haircuts even after the introduction of the Code, as was indicated in the case of Synergies Dooray Automated Ltd vs Edelweiss Asset Reconstruction Company Limited and Ors. ${ }^{3}$ Under the Code, the creditors took a 94 per cent haircut; that is, they realized INR 54 crores.

Synergies Dooray applied to the tribunal under Section 10 for initiating a resolution process, pursuant to which an interim resolution professional was appointed and a public notice issued. The total debt of the company amounted to INR 972.15 crores. Of the four resolution plans that were received, the plan by Synergies Casting Ltd received 90.16 per cent of the vote, and it was decided that debt would be sold for INR 5408.21 lakhs (amounting to about 54 crores).

This case is indicative of the fact that creditors have generally had to struggle to realize their dues and were therefore wary of the entire settlement process under the Code as well. Going by their previous experiences, they decided to accept the haircut in the hope of at least realizing some of their claims. 
As per the Bankruptcy Law Reforms Committee report, ${ }^{4}$ lenders are able to realize only 20 per cent of their dues. This clearly indicates the sad state of affairs that prevails. Credit is the lifeblood of the economy, and for successful corporate growth a constant supply of credit is essential. A firm that is freely entering the competitive corporate sector may fail to deliver as planned for various reasons. These may or not be economic; they can be social, policy driven or in some cases the result of bad faith. In any scenario the inability of one debtor to realize debts should not dampen the spirit of lending. The Indian economy has suffered in a number of ways owing to the absence of an appropriate mechanism for addressing default. One of the major setbacks suffered by the economy is a poorly developed credit market, as lenders are unwilling to lend because they fear a loss of investment and therefore lower funds at their disposal, which in turn will limit their ability to lend again (Tomasic 2006). Further, low and delayed recovery raises the cost of credit, which leads to expensive projects that are ultimately not unviable. The lack of adequate credit availability in a cash-strapped economy has further resulted in the stifling of corporate growth. Many labour-intensive industries have also taken a beating, as they have been starved of credit facilities.

The Code thus addresses business failures either by rescuing failed businesses or by releasing resources from failed businesses back into the economy, thereby promoting corporate growth and providing a seeding ground for entrepreneurship. ${ }^{5}$ Through provisions for resolution and liquidation, the Code enables lenders to recover funds from future earnings, after resolution or after the sale of liquidation assets. They can now distinguish price and credit risks across risk categories and offer differentiated and customized credit products across the value chain (Sahoo 2018). Further, the inevitable consequence of a resolution process deters management and promoters of the corporate debtor from committing a default, thereby minimizing the incidence of this. The supply of credit is thereby increased, reducing the cost of funds and developing a debt market. The Code thus addresses default and enhances the availability of credit for business. ${ }^{6}$ There has been a marked improvement in credit realization, with a sudden spurt of debt clearances by corporate debtors: 2,100 companies settled INR 83,000 crores' worth of dues immediately after the implementation of the Code. ${ }^{7}$ Therefore the Code seems to be a welcome step, as it aims at the settling of dues in a timely manner with the intention of balancing the interests of all stakeholders. 
It also needs to be pointed out that the Code facilitates the better utilization of resources while preserving the value of an enterprise (Sharma 2017). It enables the optimum utilization of resources by preventing the use of resources below the optimum level, ensuring efficient resource use within the firm through the resolution of insolvency and by releasing unutilized or underutilized resources so they can be used efficiently through closure of the firm. The Code thus addresses the inefficiency of resource utilization and thereby maximizes the value of assets. It is believed that if resources that are currently unutilized or underutilized for whatever reason can be put to more efficient use the growth rate may well go up by a few percentage points, other things being equal, particularly when this is accompanied by the availability of credit and entrepreneurship, as observed by Jongho Kim (2009: 119).

\section{Features of the Code: Four Pillars}

The Code rests on four pillars: the regulator (the Insolvency and Bankruptcy Board of India), the adjudicatory body (national company law and the appellate tribunal), insolvency professionals and information utilities. These will now be briefly discussed.

\section{Regulator}

Under Section 188, the Code envisages the setting up of an Insolvency and Bankruptcy Board of India. The Board will regulate all matters related to insolvency and bankruptcy, set out eligibility requirements for insolvency intermediaries (insolvency professionals, professional insolvency agencies and information utilities), regulate entry, registration and exit of insolvency intermediaries, make model by-laws for professional insolvency agencies, set out regulatory standards for insolvency professionals, specify the manners in which information utilities can collect and store data, and oversee the functioning of insolvency intermediaries and the resolution process.

\section{Adjudicatory Authority}

Under Section 60 of the Code, it is envisaged that corporate persons shall be adjudicated upon by the National Company Law Tribunal and the Appellate Authority, based on the territorial jurisdiction within which the corporate person in question is located. 


\section{Information Utilities}

Information utilities are repositories of financial information established under the Code in order to remove information asymmetry from the insolvency processes. They help the Code to attain uniformity in transactions and transparency, ensuring that information asymmetry does not prejudicially affect the rights of the stakeholders. Chapter V of the Code details the broad framework for the formation, governance and core activities of information utilities. The process envisaged for the working of information utilities is summarized in Figure 1.

FIGURE 1. Working of the information utilities

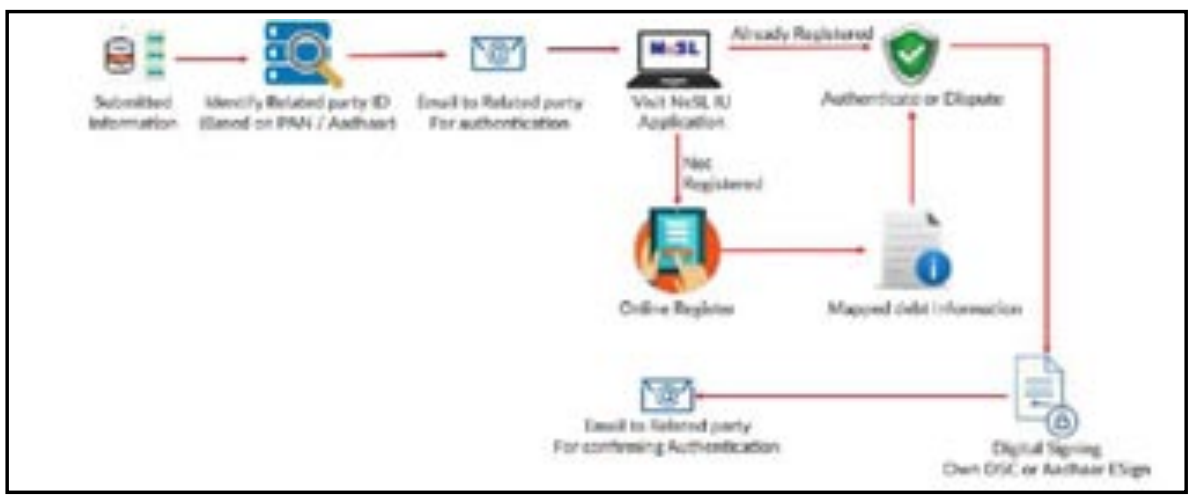

The core activities as envisaged by the Code include collection, collation, authentication and dissemination of financial information of debtors in a universally accessible format, to allow creditors to access such information and ensure there is no lopsided supplying of information that gives undue advantage to any of the stakeholders. Access to this information is given to the resolution professionals, creditors and other stakeholders in the insolvency resolution process, so that all stakeholders can make decisions based on the same information (Sahoo 2018). It is pertinent to note that to date only one information utility has been created, the National e-Governance Service. This organization, headed by Mr S. Raman, has already signed and executed about 85 contracts and has brought on board a significant amount of financial information. This is likely to pave the way for the successful automation of creditor agreements as well as bringing about significant transparency within India's credit ecosystem. A brief summary of the transactions is given in Table 1. 
TABLE 1. Success of the information utilities

\begin{tabular}{|c|c|c|c|c|c|c|c|c|c|c|c|c|}
\hline \multirow[t]{2}{*}{$\begin{array}{l}\text { As the end } \\
\text { d Quarter }\end{array}$} & \multicolumn{2}{|c|}{$\begin{array}{c}\text { Cruditors } \\
\text { having } \\
\text { Agreenent }\end{array}$} & \multicolumn{2}{|c|}{$\begin{array}{l}\text { Creditors } \\
\text { who have } \\
\text { Subanitted } \\
\text { information }\end{array}$} & \multicolumn{2}{|c|}{$\begin{array}{l}\text { Debtors } \\
\text { whom } \\
\text { information is } \\
\text { Submittod }\end{array}$} & \multicolumn{2}{|c|}{$\begin{array}{l}\text { Iman recands } \\
\text { onbosrded }\end{array}$} & \multicolumn{2}{|c|}{$\begin{array}{c}\text { User } \\
\text { Registrations } \\
\text { by Debions }\end{array}$} & \multicolumn{2}{|c|}{$\begin{array}{l}\text { Loen reconds } \\
\text { Auctwendated } \\
\text { by Decton }\end{array}$} \\
\hline & $\mathrm{FCs}_{\mathrm{s}}$ & OCs & $\mathrm{FCs}_{\mathrm{s}}$ & $\mathrm{OCS}_{\mathrm{S}}$ & $F C s$ & $\alpha_{s}$ & $\mathrm{RCs}_{s}$ & OCs & $F G$ & $\alpha_{s}$ & $F_{a}$ & $\infty_{s}$ \\
\hline june, 2018 & 66 & NA & 21 & 106 & 69184 & $\Omega$ & 191247 & 105 & 1024 & 10 & 1364 & us \\
\hline $\begin{array}{l}\text { September. } \\
2018\end{array}$ & 85 & NA & 40 & 144 & 2016709 & 530 & 1222737 & 200 & SIII & 10 & 6079 & 32 \\
\hline
\end{tabular}

\section{Insolvency Professionals}

The insolvency professional takes care of the administrative functions of the corporate debtor once the adjudicatory authority admits the application for the Corporate Insolvency Resolution Process (CIRP) ${ }^{8}$ that is, it manages the affairs of the company after the promoters and the management handover control to the committee of creditors (Eshawar 2016). The Code gives considerable powers to the insolvency professionals, and with their growing numbers it is likely that a specialized cadre of officers specializing in resolution process will be created to help better implementation of the Code. Their numbers are briefly given in Table 2 .

TABLE 2. Number of registered information professionals

\begin{tabular}{|c|c|c|c|c|}
\hline Car/ hagion & 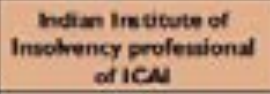 & 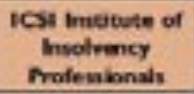 & 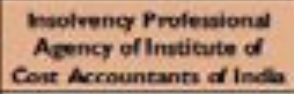 & Total \\
\hline New Delik & 250 & 172 & 42 & 464 \\
\hline Rest of Northers Region & 171 & 107 & $\boldsymbol{v}$ & 105 \\
\hline Mumbai & 232 & 76 & 20 & 228 \\
\hline Rest of Western Resion & 163 & 74 & 21 & 258 \\
\hline Oumai & 79 & 46 & 7 & 132 \\
\hline Reet of Southern Regon & 193 & 119 & 31 & 343 \\
\hline Kollats & 116 & 26 & 10 & 152 \\
\hline Rent deastam Region & 39 & II & 5 & 55 \\
\hline Al Inda & 1243 & 631 & 163 & 2037 \\
\hline
\end{tabular}

Insolvency professionals also have the responsibility of collecting information relating to assets, finances and operations, determining the financial position of the corporate debtor, collection and consolidation of claims from creditors and most importantly the constitution of the committee of creditors (Vivek 2018). They must adhere to the strict code of conduct as laid down by the Code and take reasoned and judicious decisions, comply with all the requirements and terms and conditions specified in the by-laws of the insolvency professional agency and submit to the authority of the agency of which he is a member. The 
insolvency professional is in charge of conducting the entire resolution process, including taking custody and control of all assets, representing and acting on behalf of the corporate debtor (Jain 2017: 38), convening and attending meetings of the committee of creditors, preparing information memorandum and inviting resolution applicants to put forward resolution plans.

\section{Other Features}

1. Going from debtor in possession to creditor in possession

The Code has made a significant departure from the erstwhile concept of debtor in possession to creditor in possession. The Code allows creditors to assess the viability of the corporate debtor while keeping a check on the profitable assets and ensuring that the best practical decision is taken, in order to keep all the stakeholders satisfied while at the same time ensuring that the corporate debtor continues as a going concern. The Code therefore marks a shift from a debtor centric liquidation process to a creditor-determined resolution process. The idea of giving the debtor innumerable chances to survive, with the fond hope that it will revive and rise as a phoenix from the ashes is done away with (Salim 2007). In the present regime, businesses that do not perform well will perish faster, making resources available for other entrepreneurs, rather than merely prolonging an inevitable death. It should be noted that the Code marks a substantial change in legislative policy relating to corporate insolvency, wherein creditors in general and financial creditors in particular are substantially empowered to obtain the debts that are due to them (Sriram 2016). The fate of the Code rests in the change in mindset of the creditors and the work that insolvency professionals render (Pandian 2016: 62-66).

2. Information memorandum and resolution plan

The resolution professional is required to prepare an information memorandum that consists of the information required by a resolution applicant to make the resolution plan; it should include relevant financial information (Anirudh 2018). The resolution professional must invite prospective resolution applicants who fulfil the criteria laid down by him, with the approval of the committee of creditors, who will then use the information memorandum to prepare a resolution plan. The invited resolution applicant shall not be eligible to submit a resolution plan if he is an undischarged insolvent, is a wilful defaulter, has an account classified as NPA, 
has been convicted with imprisonment for more than two years, is disqualified from acting as a director or does not comply with all other such provisions of Section 29A of the Code. Further, the resolution professional must examine each submitted plan and verify whether it meets all the prerequisites specified in the Act.

3. Stringent timelines

The Code prescribes very strict timelines that are required to be adhered to for the successful culmination of proceedings that are filed under the Code. The adjudicating authority is mandated to hear and decide whether to admit, reject or point out defects in the application that requests a resolution of debt either by the financial creditor, the operational creditor or a corporate applicant a maximum of 14 days from the date of filing. ${ }^{9}$ Once the adjudicatory authority admits the plea for resolution, the entire resolution process must be completed within 180 days, ${ }^{10}$ with a maximum extension of 90 days. ${ }^{11}$ The committee of creditors is mandated to fit all procedural requirements within this strict schedule. The Code provides punitive measures in the form of the compulsory liquidation of the commercial entity if the deadlines are violated. ${ }^{12}$ These deadlines are one of the most important features of the Code, as they ensure that the timely resolution of debt is achieved. The Code shies away from giving any discretionary powers to the adjudicatory authority, as were given under the SICA to the Board for Industrial Finance and Reconstruction.

4. Special classes of creditors

The Code has made significant efforts to streamline the various ambiguities that often resulted in faulty interpretations, prolonged legal battles and undue delays in the settling of commercial entities' debts (Wood 2010). The Code has identified different types of creditors and gives them differential rights. Apart from the regular creditors, in the form of decree holders and bond holders, the Code draws a distinction between financial creditors, operational creditors and other creditors. Financial creditors are identified as those who have lent out any financial debt as defined under the Code. ${ }^{13}$ The Code further identifies operational creditors as a separate category. Under the previous law the rights of employees were often in jeopardy whenever a company went into liquidation. ${ }^{14}$ With the definition of operational creditor including within its ambit employees of the company, there is a certainty with respect to the claiming of dues from the company. 


\section{Defining Features of the Code}

It is safe to say that the Code has evolved significantly in terms of its introduction of new concepts and improving earlier principles. The Code has introduced the committee of creditors, ${ }^{15}$ as discussed earlier, which takes the decision either to liquidate the corporate debtor or to resurrect it as a going concern. The committee of creditors solely comprises the financial creditors. Secondly, the Code has imposed a moratorium over all the contracts and obligations of the corporate debtor for the entire duration that the insolvency proceedings are in force. ${ }^{16}$ This ensures that the corporate debtor does not surreptitiously alienate any of the properties to the detriment of the corporate debtors. Lastly, it is worthwhile noting that the Code has made significant efforts to incorporate the United Nations Commission on International Trade and Law (UNCITRAL) principles that govern insolvency laws within the Code. ${ }^{17}$ The principles provide rules for ensuring certainty in the market to promote efficiency and growth, allow maximization of the value of assets, strike a balance between liquidation and reorganization, ensure equitable treatment of similarly situated creditors and establish provisions for the timely, efficient and impartial resolution of insolvency. They also make provisions for the preservation of the insolvent estate, in order to allow equitable distribution to creditors, while at the same time ensuring a transparent and predictable insolvency law that contains incentives for gathering and dispensing information (Ravi 2015). The principles make provisions for the recognition of existing creditor rights and the establishment of clear rules in order to rank the priority of claims. They also emphasize the establishment of a framework for cross-border insolvency. It is worthwhile to note that almost all these provisions have been incorporated in some manner within the Code.

\section{Process of CIRP as Envisioned within the Code}

Part II of the Code deals with matters relating to the insolvency and liquidation of companies and limited liability partnership firms where the minimum amount of the default is rupees one lakh; this amount can be increased to rupees one crore by central government. ${ }^{18}$ The application may be filed either by the financial or operational creditor or the corporate applicant himself. The adjudicating authority either accepts or rejects the application within a period of 14 days. Once the application has been accepted an automatic moratorium is imposed on all contractual and legal proceedings pertaining to the corporate debtor. 
Simultaneously an insolvency professional is appointed and a public announcement to the effect is made. The insolvency professional then convenes a meeting of the committee of creditors, constituting only financial creditors, and works on a resolution plan to be submitted to the adjudicatory authority within a period of 180 days. If the committee of creditors is unable to reach a viable solution, the corporate debtor moves towards liquidation, in which case the insolvency professional will become the official liquidator. The process of insolvency as envisioned in the Code is summarized in Figure 2.

FIGURE 2. CIRP followed under the Code

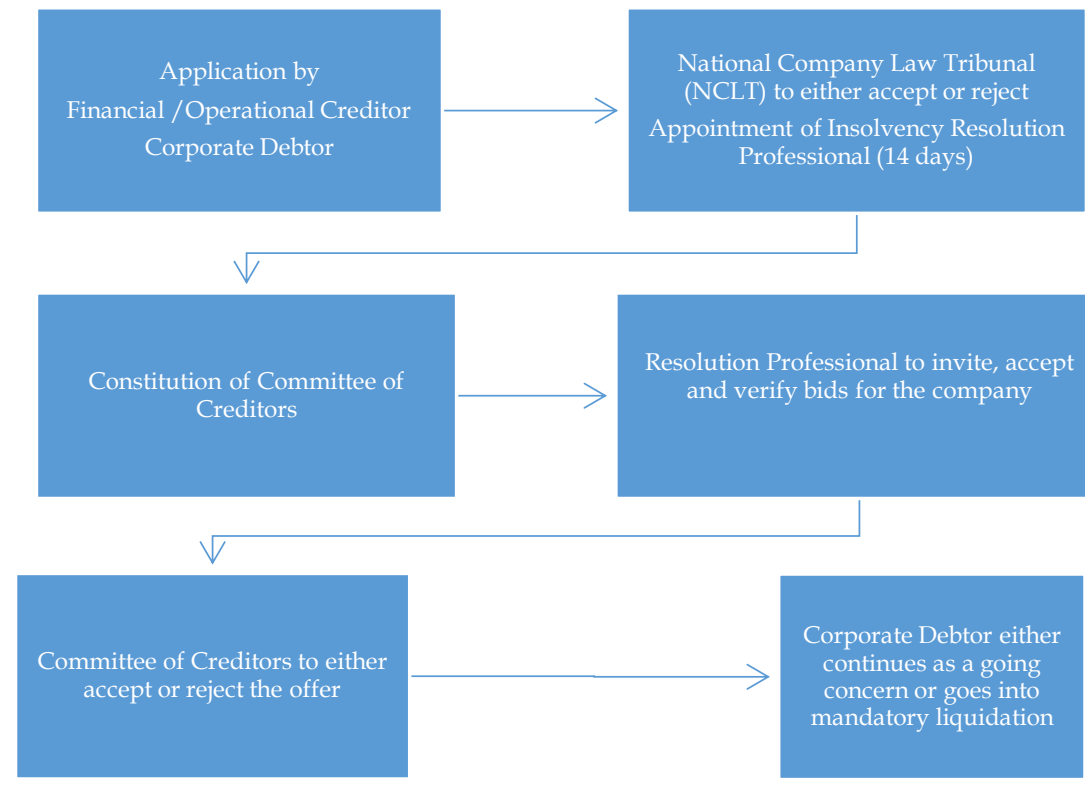

\section{Challenges}

The Code is in its nascent stage and is naturally besieged with various teething problems. However, it is pertinent to note that there seem to exist certain fundamental problems and ambiguities within the framing of the law itself. It has been pointed out that no law is perfect from its inception and always comes with some grey areas. With appropriate delegated legislation and judicial interpretation, these problems can be ironed out.

\section{Stringent Timelines}

The stringent timelines under the Code are a welcome step as they bring certainty, limit the scope for any dilatory tactics and also ensure 
the maintenance of asset values allowing the creditors' debts to be paid. However, these strict timelines are considered a bane rather than a boon by various commentators. The law is clear that the entire process, including listing of claims, settling disputes with operational creditors, inviting bids, deliberating on them, accepting a final bid from prospective buyers for the company and final reorganization, resolution and liquidation must end within 180 days, which is extendable by 90 days. This seems to be unfair as many companies do not have adequate time to fully analyse the relevant financial information and respond within the stipulated time period with an adequate representation (Umarji 2016). The stringent timelines leave no scope for the committee of creditors and the insolvency professional to be thorough in their approach or to receive maximum offers for rehabilitation; this greatly reduces competition among bidders.

One case in point is that of Bhushan Steel, one of the 40 cases that were referred to the adjudicating authority by the Reserve Bank of India, having a debt of INR 45,000 crores. In this case the insolvency professional was approached by two bidders, Tata Steel and JSW Steel, who submitted their bids on the last appointed day. However, soon after this date a resolution proposal was received from Liberty House, a British steel giant. The insolvency professional refused to accept the bid since it was submitted after the due date. However, the company approached the adjudicating authority and invoked its discretionary jurisdiction, citing the non-availability of complete information on Bhushan Steel in the limited timeframe. This meant that they were unable to submit a proper proposal in a timely manner. For this reason, they sought permission to submit their bid to the auction. The adjudicatory authority, making use of its discretionary powers, allowed the bid to be submitted, and directed the committee of creditors to evaluate it. While the strict deadlines help creditors ensure the timely resolution of debts, it is likely to affect the bids the companies receive with regard to rehabilitation, and eventually this will affect the competition within the market. It is currently (2018) only the large conglomerates who have managed to submit proposals within the stipulated time. Approximately 30 per cent of the companies have missed their conclusion deadlines and another 20 per cent are on the extended deadline. The fact is vindicated by the figures available on the subject that are given in Table 3.

Further, it needs to be pointed out that the strict timelines are also laying the foundation for excessive use of the adjudicatory authority's discretionary powers, as has been recently witnessed in Quantum Limited 
TABLE 3. Timeline followed within the CIRP

\begin{tabular}{|c|c|}
\hline Status of CIRPs & Number of $\mathrm{CIPP}$, \\
\hline Almitiod & 1190 \\
\hline Cloned on Apped / Roview & 118 \\
\hline Closed by Resoluzion & 52 \\
\hline Clowed by Liquidacion & 212 \\
\hline Ongoing CWP & 816 \\
\hline$>270 \mathrm{dm}$ & 238 \\
\hline$>180 \mathrm{dm} \leq 270 \mathrm{dm}$ & 158 \\
\hline$>90 \mathrm{dms} \leq 180 \mathrm{dms}$ & 211 \\
\hline$\leq 40 \mathrm{dap}$ & 209 \\
\hline
\end{tabular}

Note: 1. The number of days perding is from the dare of admission.

2 The mumber of dxy pending inclicder time excloded by the Trburds.

vs Indus Finance Corporation. In this case the extension application was filed after the expiry of the 180-day period, that is on the 181st day, citing non-consensus by the committee of creditors on a resolution proposal. The appellate tribunal allowed the application on a narrow interpretation of the Code, stating that it does not stipulate that the application for extension be made within the 180 days. Similarly, in another case where the creditor stalled the resolution process without citing any reason, the National Company Law Appellate Tribunal (NCLAT) directed the committee of creditors to re-evaluate the proposal for rehabilitation, even though the mandatory 270 days had elapsed. This was one of the first cases to be filed under the Code, and the dilatory tactics led not only to huge losses but also to the shutting down of a going concern. This decision of the appellate authority was based on the reasoning of the wider public good. ${ }^{19}$

\section{Differential Treatment Meted out to Different Classes of Creditors}

An analysis of the Code demonstrates that differential treatment is meted out to different classes of creditors. As discussed above, while financial, operational, secured and unsecured creditors are separately defined, the committee of creditors is constituted only of financial creditors, keeping out all the others. ${ }^{20}$ The committee of creditors decides the path the corporate debtor eventually takes, be it liquidation or resolution; other creditors have no say in this. Similarly, when it comes to the settlement of dues as enumerated in Section 53 of the statute, the terms secured and unsecured creditors are used without naming financial or operational creditors. This differential treatment within the statute is likely to reduce its efficacy (Ramamurthy 2016). 
This differential treatment has raised a huge problem amongst the various operational creditors, who believe that it is because of their efforts that the companies operate; by omitting them from the key decision-making process, their rights are prejudicially affected. This issue was raised by the operational creditors of Binani Cement, ${ }^{21}$ which was undergoing insolvency proceedings, wherein it was argued that the operational creditors should be allowed as much say in money matters as anybody else. They proved their point by stopping all supplies of materials to Binani Plant. Ultimately the Supreme Court relented and directed the insolvency professional to record their claims and allow them a seat at the table. This was an instance of the excessive use of discretionary power by the adjudicating authority. The IBBI has amended the law that compels the committee of creditors to submit a written report, clarifying the manner in which the rights of all the creditors are settled. Further, a subsequent amendment in October 2018 has mandated the committee of creditors to settle the dues of the operational creditors before those of the financial creditors. These changes appear to be positive, yet closer scrutiny reveals that they are just knee-jerk reactions to the various contests taking place before the adjudicating authority. As a responsible regulator, the IBBI needs to stop making changes within the law on a regular basis just because of some challenge or other. It is likely that if this trend continues, the original Code will be changed beyond recognition, with negative effects for the economy.

There have been other instances where either the creditor was not given his due on account of the misinterpretation of definitions in the Code or the non-existence of rights within it. One case is that of Nikhil Mehta and Sons vs M/s AMR Infrastructure $L t d{ }^{22}$ in which home buyers were given the status of financial creditors. Subsequently, an amendment was brought about by the IBBI recognizing them as such. It is pertinent to point out, though, that even though the amendment refers to home buyers as financial creditors, no commensurate rights have been handed over under Section 53 of the Code, which shies away from defining creditors as identified earlier.

Various other cases have been found to falter when they interpreted the term 'creditor', for example Jaypee Infratech Limited, ${ }^{23}$ and Col. Vinod Awasthy vs AMR Infrastructures Ltd. ${ }^{24}$

\section{Too Much Power in the Hands of the Committee of Creditors}

It is imperative to note that the committee of creditors has been given significant power to decide the fate of the corporate debtor, whether it 
will be a going concern or whether it will be liquidated. In the absence of any specific guidelines with respect to the manner in which decisionmaking will take place, it is likely that the committee of creditors will assume considerable powers over the corporate debtor, which may not be in the public interest (Chaudhary and Kapoor 2016). In certain recent cases the prudence behind committee of creditors' decisions has been questioned. In the case of Rave Scans, the committee of creditors decided against a proposal without citing any specific reason, even though the creditors were getting INR 51 crores in response to a debt of INR 36 crores. Situations like this need to be curbed in order to ensure that the efficacy of the statute is not undermined.

\section{Liability of the Insolvency Professional}

As discussed above, the insolvency professional has the responsibility of running the company after insolvency proceedings have been initiated and a moratorium on all the contracts and legal proceedings has been imposed. The Code is silent with respect to the qualifications of the insolvency professional and the required capabilities of the person appointed to run the entire business as a caretaker. While the professional only takes care of the administrative functions, one cannot be oblivious to the possibility that irreparable damage will be caused to the corporate debtor.

A case in point is that of Mr Mukesh Mohan, who allegedly manipulated the committee of creditors, presented only a few of the resolution proposals and in some matters circumvented the committee of creditors altogether in order to take decisions with regard to the resolution process. This proved to be detrimental to the corporate debtor and the entire resolution process. Similarly, in the case of MsRuia, the insolvency professional decided to change the entire management of the company including the chief executive officer, for a period of one month, and charged a fee of INR 14 crores when the corporate debtor's total debt was only 4,16 crores.

In both these cases, IBBI held the persons involved liable for misconduct and violation of the basic principles of the Code. However, nothing fruitful is likely to emerge from this, since the duties of the insolvency professional only mention good faith when it comes to avoiding liability for erroneous decisions. It is imperative that rules and regulations be drafted to identify the exact job description of the insolvency professional. 


\section{Silence on Third-party Contracts}

The Code is surprisingly silent on the impact of potential third-party contracts between the committee of creditors and any outside party that could not bid at the auction either voluntarily or because it missed the deadline. There is no clause in the law that forbids the committee of creditors from accepting a profitable offer that promises higher returns to the creditors and ensures the company continues as a going concern (Singh 2017). The Code does not bar the creditors either collectively or individually from contracting with such a third party. This situation arose in the recent case of Monnet Ispat, wherein the proposers failed to make the due proposals in time and subsequently approached the corporate debtor for an out of court settlement. The matter is subjudice at the time of writing and details are not available. While the Code imposes a moratorium on the existing agreements and contracts that are operative between the stakeholders and the corporate debtor, there is no such bar on creditors with third-party interests.

\section{Variance in Behaviour of Stakeholders at Odds with the Overall Objective}

It is possible that each stakeholder will have his own interest, and these interests can often diverge from the stated overarching objectives of the resolution process. The stakeholders are expected to behave in a manner that maximizes value for themselves (Sullivan et al. 1987). Without explicitly recognizing the variations in interests and the likely behavioural patterns brought about, the stipulated standard resolution process may not be the most optimal. Hence the behaviour of the various stakeholders needs to be modelled in detail, and this should lead to appropriate allowances and improvisations in the design of a resolution framework (Hemant 2017).

\section{Success of the Code}

It is pertinent to note that even with all the challenges discussed above, the success rate of the Code cannot be undermined. It has managed to bring the insolvency laws into focus with a possible tilt towards the resolution of debts and the reorganization of companies that are resurrected rather than shut down. Over the two years from October 2016 as many as 1,200 companies have approached the process under the Code and gone into liquidation, of which approximately 400 cases have 
been concluded and the rest are in different stages of CIRP, as shown in Table 4.

TABLE 4. Number of CIRPs by sector

\begin{tabular}{|l|r|r|r|}
\hline Sector & Closed & Running & Total \\
\hline Manufacturing & 172 & 350 & 522 \\
\hline $\begin{array}{l}\text { Food, beverages } \\
\text { and tobacco products }\end{array}$ & 14 & 47 & 61 \\
\hline Chemicals and chemical products & 14 & 40 & 54 \\
\hline Electrical machinery and apparatus & 15 & 40 & 55 \\
\hline $\begin{array}{l}\text { Fabricated metal products except } \\
\text { machinery }\end{array}$ & 12 & 25 & 37 \\
\hline Machinery and equipment & 32 & 38 & 70 \\
\hline $\begin{array}{l}\text { Textiles, leather } \\
\text { and apparel products }\end{array}$ & 30 & 52 & 82 \\
\hline $\begin{array}{l}\text { Wood, rubber, plastic } \\
\text { and paper products }\end{array}$ & 13 & 26 & 39 \\
\hline Basic metal & 33 & 66 & 99 \\
\hline Other metal & 9 & 16 & 25 \\
\hline $\begin{array}{l}\text { Real estate, renting and business } \\
\text { activities }\end{array}$ & 68 & 141 & 209 \\
\hline Construction & 27 & 97 & 124 \\
\hline Wholesale and retail trade & 52 & 71 & 123 \\
\hline Hotels and restaurants & 12 & 21 & 33 \\
\hline Electricity and others & 10 & 19 & 29 \\
\hline $\begin{array}{l}\text { Transport, storage } \\
\text { and communications }\end{array}$ & 10 & 19 & 29 \\
\hline Others & 31 & 98 & 129 \\
\hline Total & $\mathbf{3 8 2}$ & $\mathbf{8 1 6}$ & $\mathbf{1 1 9 8}$ \\
\hline
\end{tabular}

It is worthwhile noting that the running rate of insolvencies after its inception has been remarkable, considering the hiccups faced in terms of interpretation of various terms, ambiguities with respect to deadlines, rights of various stakeholders and insolvency professionals, and so on. It may be noted that despite these problems numerous (269) voluntary liquidation applications have been filed, of which only six have been concluded. Further, the decision of the RBI to refer the biggest defaulters, amounting to 25 per cent of the present NPAs, has helped bring credence to the law as having the complete faith of the state and favouring all stakeholders equally. The list has been extracted in Table 5 for ready reference. 
TABLE 5. Companies Preferred by the Reserve Bank of India for CIRP

\begin{tabular}{|c|c|c|c|}
\hline & & $\begin{array}{l}\text { List of } 15 \\
\text { Companies }\end{array}$ & Referred by RBI \\
\hline S.No & $\begin{array}{l}\text { Name of the } \\
\text { Company }\end{array}$ & $\begin{array}{l}\text { Debt Value } \\
\text { (in Crore) }\end{array}$ & Status \\
\hline 1 & Bhushan Steel & 44,478 & Tata Steel has acquired the firm \\
\hline 2 & Jyoti Structures & 5,165 & $\begin{array}{l}\text { Resolution plan pending for approval } \\
\text { with the National Company Law Tribunal } \\
\text { (NCLT) }\end{array}$ \\
\hline 3 & Essar Steel & 37,284 & $\begin{array}{l}\text { Bids by Arcelor Mittal and Numetal } \\
\text { disqualified. Disqualification challenged } \\
\text { before the NCLT }\end{array}$ \\
\hline 4 & $\begin{array}{l}\text { Era Infra } \\
\text { Engineering }\end{array}$ & 10,065 & Admitted for insolvency proceedings \\
\hline 5 & $\begin{array}{l}\text { Monnet Isapt and } \\
\text { Energy } \\
\end{array}$ & 12,115 & $\begin{array}{l}\text { Resolution plan submitted by Aion JSW } \\
\text { approved by NCLT }\end{array}$ \\
\hline 6 & Alok Industries & 22,075 & $\begin{array}{l}\text { Committee of creditors approves joint } \\
\text { resolution plan submitted by RIL and JM } \\
\text { Financial ARC }\end{array}$ \\
\hline 7 & Electrosteel Steels & 10,273 & Vedanta has acquired the firm \\
\hline 8 & Amtek Auto & 14,074 & $\begin{array}{l}\text { Liberty House declared as the highest } \\
\text { bidder but challenged by resolution } \\
\text { professional. Matter pending with the } \\
\text { NCLT }\end{array}$ \\
\hline 9 & ABG Shipyard & 6,953 & $\begin{array}{l}\text { NCLT has directed resolution professional } \\
\text { to consider Liberty House bid }\end{array}$ \\
\hline 10 & Lanco Infratech & 44,364 & $\begin{array}{l}\text { Committee of creditors deciding on the } \\
\text { resolution plan submitted by Thriveni } \\
\text { Earthmovers }\end{array}$ \\
\hline 11 & Jaypee Infratech & 9,635 & $\begin{array}{l}\text { IBBI and resolution professional have } \\
\text { appealed to the Supreme Court to revive } \\
\text { the insolvency process. }\end{array}$ \\
\hline 12 & $\begin{array}{l}\text { Bhushan Power } \\
\text { and Steel }\end{array}$ & 37,248 & $\begin{array}{l}\text { Tata Steel, Liberty House in race. Matter } \\
\text { pending before the National Company } \\
\text { Law Appellate Tribunal (NCLAT) } \\
\end{array}$ \\
\hline 13 & IVRCL & $13,405.92$ & Matter referred to NCLT \\
\hline 14 & $\begin{array}{l}\text { Ruchi Soya } \\
\text { Industries Ltd }\end{array}$ & 5,500 & Matter referred to NCLT \\
\hline 15 & Orchid Pharma Ltd & 3200 & Matter referred to NCLT \\
\hline
\end{tabular}

The success of any statute is discernible from the manner in which the obstacles that arise are taken care of. Various cases that have been discussed above should be read not only as challenges but also as success stories. For example, Essar Steel has managed to bring on board all the qualified bidders, while ensuring that there is no circumvention of the law in terms of Section 29A of the Code, which prohibits promoters and related parties from bidding for corporate debtors. 


\section{Conclusion}

The Insolvency and Bankruptcy Code has made significant efforts to revamp the entire credit ecosystem in India by amending and repealing the old foundations of the insolvency processes. The Code promises to bring about far-reaching reforms with an emphasis on creditor-driven insolvency resolution. It aims at the early identification of financial failure and thereby at maximizing the asset value of insolvent firms. A unified regime envisages a structured and time-bound process for insolvency resolution and liquidation, which should significantly improve debt recovery rates and revitalize the ailing Indian corporate bond market.

The enactment and implementation of the Code will not only improve Indian world rankings in terms of the ease of doing business but will also improve the credit market, gross domestic product, foreign direct investment and the business environment as a whole. However, the success of the Code will be dependent on the manner in which its provisions are implemented. There is ample proof that the law is on the right path, with the number of successful resolutions hitting double digits in less than two years. However, one should not become too complacent as challenges remain; these have been discussed above in some detail and pertain to legal, logical and procedural hurdles. The coming months will be crucial in ensuring that the challenges are addressed with the least possible tweaking of the existing legislation. However, the success story of the Code cannot be lost sight of merely because of a few challenges. The growth trajectory depicted by the Code is indicative of significant improvements in the insolvency regime in India.

ANKEETA GUPTA is an LLM from the National Law School of India University, Bangalore. She worked with the Faculty of Law University of Delhi, India, as an assistant professor and is pursuing a PhD from the same institution. Ankeeta is an avid researcher who undertakes work in the field of corporate law and is currently working on the Insolvency and Bankruptcy Law of India passed in 2016. Email: ankeeta27@gmail.com

\section{NOTES}

1 Statement of objects and reasons, Insolvency and Bankruptcy Code, 2016.

2 Innoventive Industries Limited vs. ICICI Bank and another. Decided by the Supreme Court on 31 August 2017.

3 Synergies Dooray's Insolvency Proceedings. 
4 Government of India, The Report of the Bankruptcy Law Reforms Committee Volume I: Rationale and Design, 2015. http://ibbi.gov.in/BLRCReportVol1_04112015.pdf.

5 Message by M.S. Sahoo, Chairperson IBBI, in communication to Insolvency and Bankruptcy Journal, 2017.

6 Ibid.

7 'Owners settle Rs.83k-cr bank dues', Times of India, 23 May 2018, p. 17. https:/ / timesofindia.indiatimes.com/business/india-business/owners-settle-rs-83k-crore-bankdues/articleshow/64279946.cms.

8 Section 3(19) and 207 of the Code.

9 Section $7,8,9$ respectively.

10 Section 12(1).

11 Section 12(3)

12 Section 33.

13 Defined under section 5(8): (8) 'financial debt' means a debt along with interest, if any, which is disbursed against the consideration for the time value of money and includes(a)money borrowed against the payment of interest; (b)any amount raised by acceptance under any acceptance credit facility or its de-materialized equivalent; (c) any amount raised pursuant to any note purchase facility or the issue of bonds, notes, debentures, loan stock or any similar instrument; (d) the amount of any liability in respect of any lease or hire purchase contract which is deemed as a finance or capital lease under the Indian Accounting Standards or such other accounting standards as may be prescribed; (e) receivables sold or discounted other than any receivables sold on nonrecourse basis; (f) any amount raised under any other transaction, including any forward sale or purchase agreement, having the commercial effect of a borrowing; (g) any derivative transaction entered into in connection with protection against or benefit from fluctuation in any rate or price and for calculating the value of any derivative transaction, only the market value of such transaction shall be taken into account; (h) any counter-indemnity obligation in respect of a guarantee, indemnity, bond, documentary letter of credit or any other instrument issued by a bank or financial institution; (i) the amount of any liability in respect of any of the guarantee or indemnity for any of the items referred to in sub-clauses (a) to (h) of this clause.

14 Bank of Maharashtra vs Pandurang Keshav Gorwardkar E Ors, 2013 (6) SCALE 716.

15 Section 21.

16 Section 14.

17 Text of the UNCITRAL Guide to Insolvency. https://www.uncitral.org/pdf/english/texts/insolven/05-80722_Ebook.pdf.

18 Section 4 of the Code.

19 M/s Rave Scans Private Limited.

20 Section 21 of the Code.

21 http://ibccases.com/nclt/bank-baroda-v-binani-cements-ca-20-2018-cp-3592017/.

22 Decided on 23 January 2017 by the Supreme Court of India.

23 Decided on 16 May 2018 by National Company Law Tribunal, Kolkata.

24 Decided on 20 February 2017 by National Company Law Tribunal, Principal Bench Delhi. 


\section{REFERENCES}

Anirudh, Pradeep Kare 2018. 'Corporate Viaticum and Where We Stand in the World: An Analysis'. The Chartered Accountant 66 (7): 45-50.

Ayotte, Kenneth and David A. Skeel 2010. 'Bankruptcy or Bailouts?'. Journal of Corporate Law 35 (3): 469-498.

Bainbridge, Stephen M. 2007. 'Much Ado About Little? Directors' Fiduciary Duties in the Vicinity of Insolvency'. Journal of Business and Technology Law 1 (2): 335-369.

Chandrasekhar, C.P. 2018. 'Lucrative Defaults by Hungry Corporates'. EPW 53 (19): 10.

Chaudhary, Vineet and Alka Kapoor 2016. 'Corporate Insolvency Resolution Process - Brief Analysis and Challenges'. Chartered Secretary 46 (9): 50-55.

Davydenko, Sergei A. and Julian R. Franks 2008. 'Do Bankruptcy Codes Matter? A Study of Defaults in France, Germany, and the U.K.'. Journal of Finance 63 (2): 565-608. https://doi.org/10.1111/j.1540-6261.2008.01325.x

Dubey, G.S. 2013. 'An Introduction to the Recovery of Debts Due to Banks and Financial Institutions Act, 1993 - A Study'. Chartered Accountant Practice Journal 43: 684-692.

Eshawar, S. 2016, 'Information Utilities - Provider of Level Playing Field in Insolvency and Bankruptcy Process'. Chartered Secretary 46 (9): 71.

Ghosh, Pradip Kumar 2018. 'Evolution of Insolvency and Bankruptcy Code, 2016, Based on Judicial Interpretation and Pronouncement'. The Chartered Accountant 66 (7): 27-31.

Hemant, Manuj 2017. 'Insolvency Code: Variances in Behaviour of Stakeholders at Cross with the Overall Objective'. Insolvency and Bankruptcy Journal 1 (1): 9.

Jain, Deepak 2017. 'The Insolvency and Bankruptcy Code, 2016 - An Analysis and Opportunities for Professionals under the Code'. Chartered Secretary 47 (3): 38-42.

Jain, M.P. 2014. Indian Constitutional Law. Delhi: LexisNexis.

Jongho Kim 2009. 'Bankruptcy Law Dilemma: Appraisal of Corporate Value and Its Distribution in Corporate Reorganization Proceedings', Northwestern Journal of International Law \& Business 29 (1): 119-194.

Narayanan, M.S. 1994a. 'Industrial Sickness: Review of BIFR's Role, 1994'. Economic and Political Weekly 29 (7): 362-376.

Narayanan, M.S. 1994b. Industrial Sickness in India: The Role of BIFR. Delhi: Konark.

Pahwa, H.P.S. 2010. Sick Industries and BIFR. New Delhi: Bharat Law House.

Pandian, Arvindh 2016. 'Corporate Insolvency Resolution Process under the Bankruptcy Code and its Impact on the Companies Act'. Chartered Secretary 46 (9): 62-66.

Parmar, Niddhi 2018. 'Apex Court Reverses NCLAT's Order - A Sigh of Relief'. The Chartered Accountant 66 (7): 32-36.

Pillai, Satish 2017. 'Information Utility - the Eyes and Ears of the Bankruptcy Code'. Insolvency and Bankruptcy Journal 1 (1): 5.

Ramamurthy, G.M. 2016. 'Position of Secured Creditor in the Winding Up and in the Liquidation of Corporate Debtor'. Chartered Secretary 46 (9): 74-77.

Ravi, Aparna 2015. 'The Indian Insolvency Regime in Practice - An Analysis of Insolvency and Debt Recovery Proceedings'. Economic and Political Weekly 50 (51): 19-46.

Sahoo, M.S. 2018. 'Message to the Readers'. ICSI IPA Insolvency and Bankruptcy Journal, 1 (1): 13.

Salim, Mohammad Rizal, 2007, 'Corporate Insolvency and the Protection of Creditors'. UiTM Law Review 3: 143-167.

Sharma, M.L. 2016. 'Winding up of Companies under the Insolvency and Bankruptcy Code, 2016'. Chartered Secretary 46 (9): 78.

Sharma, Nilesh 2017. 'Corporate Insolvency Resolution Process, Under the Insolvency and Bankruptcy Code, 2016 - An Analysis'. Chartered Secretary 46 (9): 56. 
Singh, Prof. (Dr.) Ranbir 2017. 'Challenges in Insolvency Resolution Process under Insolvency and Bankruptcy Code, 2016'. Insolvency and Bankruptcy Journal 1 (1): 2.

Sriram, G. 2016. 'The Insolvency and Bankruptcy Code, 2016'. Chartered Secretary 46 (9): 32.

Srivastava, S.S. and R.A. Yadav 1986. Management and Monitoring of Industrial Sickness. New Delhi: Concept.

Sullivan, Teresa A., Elizabeth Warren and Jay Lawrence Westbrook 1987. 'The Use of Empirical Data in Formulating Bankruptcy Policy'. Law and Contemporary Problems 50 (2): 195-235. https:// doi.org/10.2307/1191500

Thakar, Mahesh and Jyptmala Thakar 2016. 'Insolvency and Bankruptcy Code, 2016'. Chartered Secretary 46 (9): 37-45.

Tomasic, Roman 2006. 'Creditor Participation in Insolvency Proceedings - Towards the Adoption of International Standards'. Insolvency Law Journal 14 (3): 173-187. https://doi.org/10.2139/ssrn.1443762

Tyagi, Vivek 2018. 'Corporate Insolvency Resolution Procedure under Indian Insolvency and Bankruptcy Code, 2016: A Comparative Perspective'. The Chartered Accountant 66 (7): 37-44.

Umarji, M.R. 2016. 'Challenges in Implementation of Insolvency and Bankruptcy Code, 2016', Chartered Secretary 46 (9): 46-49.

Wadhwa, Rakesh 2016. 'Insolvency and Bankruptcy Code, 2016'. Chartered Secretary 46 (9): 23-29.

Wood, Roderick J. 2010. 'The Definition of Secured Creditor in Insolvency Law'. Banking $\mathcal{E}$ Finance Law Review, 25: 341-360. 